\title{
Translating Rebu in Karonese Society into English
}

\author{
Milisi Sembiring \\ Universitas Quality, Medan, Indonesia
}

\begin{abstract}
The aims of this study were to translate and to describe the themes, and specific culture-bound terms of rebu clauses in SL into the TL. The research was conducted using the qualitative method. The data obtained was analyzed by using interdiciplinary approach. The corpus for this study consists of three texts, the first text was the text of mukul which consisted of the beginning of rebu in Karonese society. The second text consisted of rebu in Karonese society. Thirdly was the text of participation observation. All 121 clauses were translated and examined in this study. The focuses of the analysis were the ideational theme and culture-bound terms of rebu texts in Karonese society.

The results reveal both unmarked and marked themes in SL are higher than TL. Literal and semantic translations methods were applied to determine the direction of translating the whole texts. Translation procedures of descriptive equivalence, transference, paraphrase, transposition, omission, couplets, notes and cultural equivalence were applied to translate the rebu texts in Karonese society into English.
\end{abstract}

Key words: bound-culture terms, rebu, theme, translation strategies

\section{Introduction}

Rebu refers to something that is forbidden or must be avoided in social interactions among Karonese. This includes restrictions on communication and physical interaction, for example, touching, sitting near each other or face to face without being separated by another person, as well as not talking directly to each other. Rebu applies to three relationships among six people: between mami (mother-in-law) and kela (son-in-law), between bengkila (father-in-law) and permain (daughter-in-law), and between turangku and turangku (people connected by being in different 'in-law' relationships, for example, a man's wife's brothers' wives are turangku). Special cultural terms are used to negotiate communications under the custom of rebu, which is practiced when someone gets married. The special words, nina and ningen, are used in communications between rebu.

Problems happen in regard to transportation, when sometimes there is no space between the participants of rebu in the same car or in the same aircraft. So the customary norms of rebu are breached and practiced imperfectly. Those who have a strict interpretation of rebu are frustrated to see how some participants of rebu behave in their daily life. And Karonese people who want to have a good future due to the development of technology think rebu violates their human rights.

In this study the process of translation only focused on translation strategies, which consist of global translation and local translation. 'Global translation' refers to the method of translation and 'local translation' refers to the translation procedures.

Rebu exists especially between mami ${ }^{1}$ (wife's mother) and kela (daughter's husband), between turangku (husband's sister's husband) and turangku (wife's brother's wife), and between bengkila (husband's father) and permain (son's wife). Such relatives may not speak face-to-face with each other. They are not supposed to stay in the same house without the presence of a third person. It is also forbidden to sit on the same floor board with one's wife's mother or wife's brother's wife.

Rebu starts when Karonese get married. After the wedding ceremony there is a ceremony called the mukul marriage rite, held in the groom's parents' house. This is when the bride and groom have dinner from the same plate and the menu has been determined by the groom's parents. Belo pengkapuri (betel leaf which has been filled with areca nut, lime, tobacco and gamber is given to the bride's rebu and cigarettes are given by the groom to his rebu. He shakes hands with his mother-in-law and his sisters-in-law as they are introduced to their rebu and it is explained that they cannot speak directly to their rebu from that time. The Karonese custom of rebu is considered when mami and kela sit together on a mat, unless there are other people who sit between them, who function as the third person in communication between them.

The researcher is a native speaker of Karonese and he practices the dialog of rebu in his communication with his mami, turangku, and permen, although he lives in a big city. He can comprehend the

${ }^{1}$ Mami means literally mother's brother's wife, mother-in-law, mother-in-law's brothers' wives 
texts of rebu in Karonese society and he understands the connections among family members in Karonese society.

A chapter of the book entitled "Rebu Pada Masyarakat Karo" in Percikan Budaya Karo written by Tarigan (1988) has been translated into English by the researcher. Yunus (1995) also did research on the same text, which focused on Makna Pemakaian Rebu Dalam Kehidupan Kekerabatan Orang Batak Karo. In this study, the researcher described the cultural and syntactic frames dealing with those who use rebu in Karonese society. The Karo are one of the so-called Batak, a collective name for several linguistically and culturally related peoples - the Toba, Karo, Simalungun, Pakpak, Angkola and Mandailing - of North Sumatra (Singarimbun, 1975).

A few Karonese families still live in traditional houses, with as many as eight families living in such houses. Today there are only a few Karonese traditional houses. This type of house is unique, and requires social regulations to determine who lives in each part of the house and how they interact. They were Kalimbubu ${ }^{2}$, sembuyak $^{3}$ and anak beru ${ }^{4}$. There were so many rules accompanying the house, and all the families who lived in an adat house practiced rebu in their communication.

Translating Karonese society kinships and culture is unique and these types of texts are difficult to translate. The names for relatives in Karonese society do not exist in English. The form and content of the cultural texts of rebu in Karonese society are very different from English.

There are some pronoun politeness and culture-bound terms in Karonese language that do not exist in English. Equivalence was needed in the process of translating them into English. Finding equivalents of form and meaning is a problematic stage of translating a cultural rebu text in Karonese society into English.

\subsection{The Objectives of the Study}

The objectives of this study are to:

(1) describe the unmarked and marked themes in the rebu texts of Karonese

language and English

(2) examine the strategies of translating rebu texts in Karonese society into English

\subsection{Scope of the Study}

The scope of this study focuses on the analysis of:

(1) rebu texts in Karonese society a chapter of the book titled "Rebu Pada Masyarakat Karo" in Percikan Budaya Karo written by Tarigan (1988),

(2) the text of a mukul written by Ginting (2008) and

(2) the result of the researcher's participation observation.

\subsection{Data Analysis}

\section{Data analysis and findings}

The two kinds of data were classified into each category and organized as the center of analysis. The texts were segmented into sentences and sentences were numbered. The themes of the sentences were analyzed whether they were unmarked or marked themes.

Table 2.1 Halliday's Model Analysis of Theme in Declarative Clauses of Karonese Language

\begin{tabular}{|c|c|c|c|}
\hline & FUNCTION & CLASS & CLAUSES \\
\hline \multirow[t]{3}{*}{ Unmarked Theme } & Subject & Nominal Group : Pronoun as head & 51a, \\
\hline & & $\begin{array}{l}\text { Nominal Group : } \\
\text { Common or proper noun as head }\end{array}$ & $\begin{array}{l}2 \mathrm{a}, 4 \mathrm{a}, 6 \mathrm{a}, 8 \mathrm{a}, 9 \mathrm{a}, 10 \mathrm{a}, 12 \mathrm{a}, \\
19 \mathrm{a}, 20 \mathrm{a}, 22 \mathrm{a}, 23 \mathrm{a}, 25 \mathrm{a}, 26 \mathrm{a}, \\
27 \mathrm{a}, 30 \mathrm{a}, 31 \mathrm{a}, 38 \mathrm{a}, 47 \mathrm{a}, 48 \mathrm{a}, \\
61 \mathrm{a}, 65 \mathrm{a} .76 \mathrm{a}, 79 \mathrm{a}, 70 \mathrm{a}, \\
73 \mathrm{a}, 75 \mathrm{a}, 80 \mathrm{a}, 84 \mathrm{a}, 85 \mathrm{a}, \\
89 \mathrm{a}, 90 \mathrm{a}, 97 \mathrm{a}, 103 \mathrm{a}, 104 \mathrm{a}, \\
106 \mathrm{a}, 108 \mathrm{a}, 11 \mathrm{a},\end{array}$ \\
\hline & & Nominalization & $93 a, 65 a$ \\
\hline \multirow[t]{2}{*}{ Marked Theme } & Adjunct & Adverbial Group & $1 \mathrm{a}, 32 \mathrm{a}, 24 \mathrm{a}, 104 \mathrm{a}$ \\
\hline & & Prepositional Phrase & $\begin{array}{l}3 \mathrm{a}, 11 \mathrm{a}, 16 \mathrm{a}, 29 \mathrm{a}, 34 \mathrm{a}, 36 \mathrm{a}, \\
41 \mathrm{a}, 55 \mathrm{a}, 57 \mathrm{a}, 74 \mathrm{a}, 77 \mathrm{a}, \\
81 \mathrm{a}, 82 \mathrm{a}, 93 \mathrm{a}, 96 \mathrm{a}, 98 \mathrm{a}, \\
100 \mathrm{a},\end{array}$ \\
\hline
\end{tabular}

\footnotetext{
${ }^{2}$ Kalimbubu means wife givers

${ }^{3}$ Sembuyak means agnate which relates to members of the same lineage or subclan

${ }^{4}$ Anak beru means wife taker
} 
The unmarked themes of SL clauses were 54 (65.34) in SL of the total data in this study. The data for unmarked themes were from nominal group which covered pronoun as a head, common or proper noun as a head, nominalization, imperative, polar interrogative, WH- element and dependent clause.

Table 2.2 Halliday's Model Analysis of Theme in Declarative Clauses in English

\begin{tabular}{llll}
\hline & FUNCTION & CLASS & CLAUSES \\
\hline Unmarked Theme & Subject & Nominal Group : Pronoun & $51 \mathrm{~b}$, \\
& & \\
\cline { 3 - 3 } & & Nominal Group : & $2 \mathrm{~b}, 4 \mathrm{~b}, 6 \mathrm{~b}, 9 \mathrm{~b}, 10 \mathrm{~b}, 19 \mathrm{~b}, 20 \mathrm{~b}, 22 \mathrm{~b}$, \\
& & Common or proper noun & $24 \mathrm{~b}, 26 \mathrm{~b}, 30 \mathrm{~b}, 31 \mathrm{~b}, 38 \mathrm{~b}, 47 \mathrm{~b}, 48 \mathrm{~b}$, \\
& & $61 \mathrm{~b}, 66 \mathrm{~b}, 76 \mathrm{~b}, 77 \mathrm{~b}, 79 \mathrm{~b}, 80 \mathrm{~b}, 84 \mathrm{~b}, 90 \mathrm{~b}$, \\
& & $96 \mathrm{~b}, 97 \mathrm{~b}, 104 \mathrm{~b}, 106 \mathrm{~b}, 108 \mathrm{~b}, 110 \mathrm{~b}$, \\
& & $111 \mathrm{~b}$ \\
\cline { 3 - 4 } & & Nominalization & $12 \mathrm{~b}, 23 \mathrm{~b}, 27 \mathrm{~b}, 65 \mathrm{~b}, 70 \mathrm{~b}, 73 \mathrm{~b}, 75 \mathrm{~b}, 85 \mathrm{~b}$, \\
& & $89 \mathrm{~b}, 93 \mathrm{~b}, 100 \mathrm{~b}$ \\
\hline Marked Theme & Adjunct & Adverbial Group & $32 \mathrm{~b}, 25 \mathrm{~b}$ \\
\cline { 3 - 4 } & & Prepositional Phrase & $1 \mathrm{~b}, 3 \mathrm{~b}, 16 \mathrm{~b}, 29 \mathrm{~b}, 34 \mathrm{~b}, 36 \mathrm{~b}, 41 \mathrm{~b}, 55 \mathrm{~b}$, \\
& & $81 \mathrm{~b}, 82 \mathrm{~b}, 57 \mathrm{~b}$ \\
\hline
\end{tabular}

\subsubsection{Analysis of unmarked theme in declarative clauses of Rebu texts in SL and TL}

There was the shift of theme from ST into TT, predicated theme in Karonese language were found on clauses $3 \mathrm{a}, 8 \mathrm{a}$, and, $37 \mathrm{a}$ and the changed to be nominal group in TT, they were found on clauses $3 \mathrm{~b}, 8 \mathrm{~b}$ and $37 \mathrm{~b}$. Example :

26a) Kata rebu ertina pantang, la metunggung, ilarang, la ijinken ngelakoken sada perbahanen.

26b) Rebu means taboo, disharmony, forbid, or avoid to do an action.

Rebu in clause 26a can not be translated into TL, it does not have its equivalence in TL. The first translation in clause 26a was done by transference and the second one had omission of kata. Rebu is a cultural activity for Karonese society, which are practiced by married men and women. It is practiced to honor the participants of rebu. In practicing rebu there are some limitations of speaking, sitting, walking, seeing and taking a bath. The participants of rebu do not talk directly, they do not sit closely and do not look at face to face. Father in law does not take a bath together with his son in law and his brother in law does not either.

Nominalization as a head in declarative clause is as follows :

93a) Kalak sierturangku harus berlainan jenis

93b) People who are erturangku must be in different gender.

Kalak sierturangku in SL and people who are erturangku in TL are heavy subjects as themes in the clauses of no 93a, 93b , the head are kalak in SL and people in TL. They were modified by sierturangku and who are erturangku.

\subsubsection{Analysis of unmarked theme in non declarative clauses of Rebu texts in} SL and TL

Table 2.3 The Unmarked Themes of Source Language in Declarative Clause, a Polar Interrogative Clause, WHElement in a WH-Interrogative, Imperative and Dependent Clauses.

\begin{tabular}{lllll}
\hline TEXT & TYPES OF CLAUSES & \multicolumn{1}{c}{ CLAUSES } & MARKED & UNMARKED \\
\hline 1 & polar interrogative & $105 \mathrm{a}$ & - & 1 \\
2 & $\begin{array}{l}\text { WH-element in a WH- } \\
\text { interrogative }\end{array}$ & $37 \mathrm{a}, 45 \mathrm{a}, 56 \mathrm{a}, 109 \mathrm{a}, 117 \mathrm{a}$ & - & 5 \\
3 & imperative & $\begin{array}{l}\text { 8a, 107a, 110a, 112a, 113a, 115a, } \\
120 \mathrm{a}\end{array}$ & - & 7 \\
4 & Dependent clause & $\begin{array}{l}5 \mathrm{a}, 11 \mathrm{a}, 15 \mathrm{a}, 58 \mathrm{a}, 59 \mathrm{a}, 67 \mathrm{a}, 69 \mathrm{a}, 71 \mathrm{a}, \\
83 \mathrm{a}, 91 \mathrm{a}, 92 \mathrm{a}\end{array}$ & & \\
& & $37 \mathrm{a}, 72 \mathrm{a}$, & - & 2 \\
5 & Dependent clause & 26 & 11 & 15 \\
\hline 6 & Total & &
\end{tabular}

In table 2.3 dependent clauses as marked theme are found at 11 clauses and unmarked themes at 2 clauses. There are two conjunctions as part of theme they are clauses $7 \mathrm{a}$ and 13a. Conjunctive and modal 
adjuncts are found on clauses 18a and 21a. Predicated as theme are revealed on clauses 8a and 12a. Adjunct as theme is found on clause 3a. Non declarative sentences of rebu texts in Karonese language consist of one polar interrogative, four WH-element in a WH- interrogative, five imperative sentences, and twelve dependent clauses. The types of clauses can be found in the table 2.3

Table: 2.4 The Unmarked Themes of Target Language in non Declarative Clause, a Polar Interrogative clause, WH-Element in a WH-Interrogative, Imperative and, Dependent clause

\begin{tabular}{|c|c|c|c|c|}
\hline TEXT & TYPES OF CLAUSES & CLAUSES & MARKED & UNMARKED \\
\hline 1 & polar interrogative & $105 \mathrm{~b}$ & - & 1 \\
\hline 2 & $\begin{array}{l}\text { WH-element in a WH- } \\
\text { interrogative }\end{array}$ & $37 \mathrm{~b}, 45 \mathrm{~b}, 56 \mathrm{~b}, 103 \mathrm{~b}, 109 \mathrm{~b}, 117 \mathrm{~b}$ & - & 6 \\
\hline 3 & imperative & $8 b, 107 b, 112 b, 113 b, 115 b, 120 b$ & - & 6 \\
\hline 4 & Dependent & $\begin{array}{l}5 b, 11 b, 15 b, 58 b, 59 b,, 67 b, 69 b, 71 b \\
83 b, 91 b, 92 b\end{array}$ & 11 & - \\
\hline 5 & Dependent & $37 b, 72 b$ & - & 2 \\
\hline Total & & 26 & 11 & 15 \\
\hline
\end{tabular}

The above clauses show that all themes for dependent, imperative, WH-element in a WH-interrogative and polar interrogative are as unmarked themes.

Let's consider some examples of the unmarked themes of SL and TL in a polar interrogative clause, WHelement in a WH-interrogative and imperative clause.

An example of WH-element in a WH-interrogative.

45a) Mami

45b) Mother in law
: Kai kin ndai , nina Kela?

: What is going on, nina Kela?

Kai and what are the unmarked themes in WH-question of SL and TL, they do not have the same structure. Kin was untranslatable, it is to emphasize the question word in SL. Ndai is an adverb of time which preceded by word question kai. In TL there was no question word followed by adverb of time. Both themes have the same meaning but they have different structure rules.

\section{Imperative}

113a) SL Bapa

113b)TL Ego's father : Choose the biggest ones ningen pak permain e

Both of pilihi and choose are imperative, they have the same position in the clauses and they have the same meaning. They are unmarked themes in the imperative clauses.

72a) Sekalak kela si meteh adat, la pang reh man ku rumah adi mamina ngenca sisada i rumah; apaika adi jumpa ntah medem i rumah la lalit jelma si deban ije, sura-surana e ugapape iorongkenna.

72b) A kela who knows adat, will not dare to come home to eat if there is only his mami alone unaccompanied by another person; especially such meeting or staying. If no one else there, that intention will be postponed by the kela.

Both clauses of number 72a) and number 72b) , Sekalak kela si meteh adat in SL and A kela who knows adat, in TL are subject as unmarked themes. The translation method used in this theme was literal translation method, se in SL as a prefix means a as indefinite article.

\subsubsection{Analysis of marked theme in declarative clauses of Rebu texts in Karonese language}

The using of prepositional phrase as the starting point of departure in KL were found in 17 clauses of the 121 total data in KL but there were only 11 prepositional phrases as mark theme in TL . Comparing to 121 clauses as the total data in KL, the prepositional phrases are only 20.57 percent in SL. This fact reveals that prepositional phrase as marked themes were mostly used of both SL and TL. The interesting point was the amount of prepositional phrase in SL was bigger than prepositional phrase in TL.

96a) Ibas kalak Karo lit telu erbage rebu, eme antara mami ras kela, rebu antara bengkila ras permain, rebu ras si erturangku

96b) In Karonese society there are three kinds of rebu namely: rebu between mami and kela, rebu bengkila and 
permain, rebu turangku and turangku.

The translation was done by literal translation, and it was workable in TL.

In Karonese language there are many prepositional phrases by using the preposition ibas and followed by other group of words, they could be found in clauses 96a, 55a, 74a, 81a, 82a, 98a. It shows the collectiveness, by saying ibas and followed by the group of words, it does not show the individuality.

\subsubsection{Translation Strategies Used in Translating in Rebu Texts in Karonese Society}

In the process of translating rebu texts in Karonese society into English, the researcher applied translation strategies, they were global translation strategy and local translation strategy. Translation strategies were available to transfer the culture-bound terms in translating rebu texts in Karonese society into English.

\subsubsection{Translation method}

Newmark's methods of translation were applied to solve linguistic and culture-bound terms in Karonese society. The researcher applied literal and semantic translation methods which methods oriented to the SL.

An example for linguistic problem :

110a) SL Ego : : Nukur telor, te permenndu pa.

110b)TL Ego : : Your permain wants to buy eggs

There are two problems in sentences 110, they are linguistic politeness and the structure of both sentences, ndu is the second possessive pronoun. The sentence rule sentence 110a in SL consists of V $+\mathrm{O}+\mathrm{S}$ and it was translated by Your permain wants to buy eggs in the TL. It consists of $\mathrm{S}+\mathrm{V}+\mathrm{O}$. The initial of the sentence in SL is nukur as verbal group but in TL your permain is used in the initial of the sentence in TL. There was the structure shift in the process of translating in 110a SL with 110b in TL. Permenndu in sentence 110a is possessive polite linguistic in SL and its translation does not exist in TL. Ndu means your in English, but your does not have a polite linguistic form. Both of them refer to possessive singular second person.

\section{Lteral Translation}

An example of using literal translation to translate sentence 91a.

91a) Adi dilaki si turangku maka turangkuna eme ndehara silihna

91b) If a man has turangku, then his turangku are "wivies of his wife's brothers.

From 91a), and 91b), themes may be realized by dependent clauses. By analyzing the characteristic of these dependent clauses, that they appear in initial of a clause and supported by rhemes in each sentences, either in SL and TL.

The clause of number 91 was translated by using literal translation method.

\section{Semantic translation}

The translation of rebu texts in SL into the TL were focused on the SL because the cultural words in SL do not have the equivalences in TL. Flexibility in the process of translation can not be avoided therefore semantic translation method was applied to transfer the meaning of SL cultural words into TL.

75a) Rumah adat Karo igelari pe rumah si waluh jabu iingani waloh jabu biasana jabuna papan.

75b) Karonese Adat house which has wooden floor is also called rumah si waloh jabu settled by 8 families.

Rumah adat Karo igelari pe rumah si waluh jabu is translated with Karonese Adat house which has wooden floor. The concepts of house is same for every family, they are a place living, living identity, and the prestige of the family. For Karonese society, it is familiar with them the arrangements of families who live in rumah adat and they practice the rakut sitelu ways of life.

\subsubsection{Procedures in translating specific culture- bound terms.}

The translation procedures which were available to transfer the message of the ST in this study are descriptive equivalent, shifts or transpositions, transference, paraphrase, omission, couplets and notes. Descriptive equivalence was dominantly applied to translate the SL into the TL.

A few examples of the clauses :

41a) Alu kata sideban kela harus beloh ngerana ernina mami 
41b) In other words, kela must be able to use the words nina mami in speaking to his mami.

In Karonese culture the participants of rebu have understood that ngerana ernina mami is a way of communicating to his rebu that his mami and both ngerana and ernina are verbs in SL and its translation is be able to use the words nina mami in speaking to his mami. Here the descriptive equivalence procedure is applied and this cultural expression was explained with the lengthy explaination.

89a) Perjabun sibagenda ibas cakap Karo ikataken lako man ntah lako mangan.

89b) Marriage like this in Karonese language is called lako man or lako mangan.

If lako man or lako mangan is translated into TL, it means the existence of a man just for eating in his new marriage. Lako man or lako mangan is a system of marriage if a brother's son was dead, his daughter in law could be married by her father in law's brother.

The specific culture-bound terms were explained in several words to transfer the meaning of the SL by using descriptive equivalent. Some of SCBT were transferred by using the paraphrase: in this procedure the meaning of the CBT is explained. Here the explanation is much more detailed than that of descriptive equivalent.

\subsection{Findings}

The findings are presented regarding to the objectives of the study. Firstly by presenting the classification of themes and describing the unmarked and marked themes of rebu clauses. Secondly, by transferring the culture-bound terms of SL into the TL. Finally the translation strategies applied to resolve the culture-bound terms.

There were 80 the topical themes in SL and 82 topical themes in TL, 34 textual themes in SL and 34 textual themes in TL, six interpersonal themes in SL and five interpersonal themes in TL. Both textual themes and interpersonal themes are little higher in SL than TL. There were the shifts in translating themes of SL into TL.

Of all the total data in this study, there were 53 ( 43,80\%) unmarked themes in SL and there were 59 unmarked themes (48.76\%) in TL. There were 23 marked themes in TL and 27 marked themes in SL.

$\mathrm{Aku}$ in $\mathrm{KL}$ as the first person singular was translated with I and ku in clause 51a is an offering of doing something by Ego and it was translated into I. Ku as the first person possessive pronoun when it is attached to a verb and it is as a prefix.

Nominal group which consists of common or proper noun are as subjects and unmarked themes in SL, they were found in 36 clauses. In translating nominal groups of SL into TL there were some untranslatable cultural terms.

Nominalization has a function as subject in declarative clauses. Each subject as unmarked theme was translated by additional information to get the message clear in the TL.

The marked themes of declarative clauses of rebu texts in SL and TL are the adverbial group and the prepositional phrase they were found in table 2.1 and 2.2 .

The addition of WH-interrogative in TL of clause 103a was caused by the shift. It has different amount of imperative after process of translating, marked themes have been found in six clauses of SL and marked themes in TL have been found in five clauses. Each dependent clauses of SL and TL has 11 marked themes and two unmarked themes.

Translating SCBT of rebu texts was focused on conveying the meaning in SL into TL. The SCBT are explained with the same meaning in the TL culture.

The first translation was done by literal translation, and after the researcher revised and restructured it, the clause in the TL was better. The second translation of sentence 29a is workable, it sounds natural in TL. There is a shift in the process of translating sentence 29 a into 29 b, the first shift was the prepositional phrase changed to noun phrase in other words marked theme in SL changed to be unmarked theme in TL. Another shift is the movement of prepositional phrase, from initial of the clause 29a into the end of the clause $29 \mathrm{~b}$ in TL.

\section{Conclusions}

The application of translation procedures and translation methods to translate the rebu texts is helpful in the process of translation.

1. From 8 Newmark's translation methods, two of them were applied in translating

Themes in SL into TL, they are literal translation and semantic translation methods and from 14 (fourteen) types of his translation procedures, there are only 7 (seven) translation procedures that were applied in translating rebu texts in SL into TL. They are: (1) transference, (2) descriptive equivalence , (3) transposition, (4) couplets ,(5) paraphrase (6) omission and (7) notes. 
The most dominant type of translation procedure that occurs in the analyzed data is descriptive equivalence (62) cases in 212 collected data or $29,24 \%$ and literal translation (45 cases in 212 collected data, or $21.22 \%$ ), followed by transference (19 cases in 212 collected data or $8.96 \% /$ ) and transposition at the third place (with only 4 cases in 212 collected data or $1.88 \%$ )

2. Of all the total data in this study, there were 53 ( $43,80 \%$ ) unmarked themes in SL and there were 59 unmarked themes ( $48.76 \%$ ) in TL. They were from nominal group which covered pronoun as a head, common or proper noun as a head, nominalization, imperative, polar interrogative, WH- element and dependent clause. The marked themes in SL clauses were 27 and in their translation of rebu clauses of Karonese language are (23) marked themes in TL.

3. There are three kinds of rebu in Karonese society, namely:

Rebu between mami and kela,

Rebu between bengkila and permain,

Rebu between turangku and turangku.

\section{Books}

[1] Tarigan, Henry. Guntur. Percikan Budaya Karo. Bandung: Yayasan Merga Silima, 1988.

[2] Yunus,.H.Ahmad., Maria, Siti., Pelawi, Kencana.S., and Gurning, Elizabeth T. Makna Pemakaian Rebu Dalam Kehidupan Kekerabatan Orang Batak Karo. Jakarta : Depdikbud Direktoral Jenderal Kebudayaan Direktoral Sejarah dan Nilai Tradisional, 1995 .

[3] Singarimbun, Masri. Kindship, Descent and Alliance among Karo Batak. Berkeley : University of California Press, 1975

[4] Ginting, M.Ukur,. Adat Karo Sirulo. Tuntunan Praktis Adat Istiadat Karo Jilid I, Medan. 2005.

[5] Halliday, M.A.K. An Introduction to Functional Grammar. Third edition. London: Arnold, 2004.

[6] Newmark, P. A Textbook of Translation. New York and London : Prentice- Hall, 1988

\section{Web-site references}

[7] http://wwwdrshadiabanjar.blogspot.com/2010/12/translation- strategies.html

[8] AIJMER, Brno Studies in English Volume 35, No. 2, 2009 ISSN 0524-6881

[91 http://englishwithlucy.com. 